\title{
The Strategy of Nazir Development in Indonesia: A Qualitative Study
}

\author{
Rahmi Edriyanti ${ }^{1}$, Muslim Marpaung $^{2}$, Sugianto $^{3}$, Uning Musthofiyah $^{4}$, Lisa Listiana $^{5}$ \\ ${ }^{1,3}$ Universitas Islam Negeri Sumatera Utara, Indonesia, rahmiedriyanti@gmail.com \\ sugianto@uinsu.ac.id. \\ 1,4,5 WaCIDS (Waqf Center for Indonesian Development and Studies), listianaica@gmail.com \\ ${ }^{2}$ Politeknik Negeri Medan, Indonesia, muslim.marpaung07@gmail.com \\ ${ }^{4}$ Universitas Merdeka Malang, uningmusthofiyah@gmail.com
}

\begin{abstract}
The purpose of this study is to identify the most important factors in determining current strategies for the development of Nazir in specific region of Indonesia and to examine how the internal and external states developing in that province. Two analyses were used in this research method: SWOT (Strength, Weakness, Opportunity, and Threats) and QSPM (Quantitative Strategic Planning Matrix). The number of respondents who filled out the questionnaire was 8 big institutional Nazir and 5 Waqf experts between September and January of 2021, respectively. The result of SWOT analysis is that Waqf institutions need to carry out WT (Weakness Threats) strategy, which is a defensive strategy. Meanwhile, the QSPM analysis discovered that the second strategy is the most priority one. Afterwards, at the conclusion of this study, the results of these particular studies as well as recommendation will be discussed.
\end{abstract}

Keywords: Development, nazir waqf, QSPM, SWOT.

\begin{abstract}
Abstrak. Tujuan dari penelitian ini adalah untuk mengidentifikasi faktor-faktor terpenting dalam menentukan strategi perkembangan nazir wakaf saat ini di provinsi tertentu di Indonesia dan untuk mengkaji bagaimana keadaan internal dan eksternal berkembang di provinsi tersebut. Dua analisis digunakan dalam metode penelitian ini: SWOT (Strength, Weakness, Opportunity, dan Threats) dan QSPM (Quantitative Strategic Planning Matrix). Jumlah responden yang mengisi kuesioner adalah 8 orang dari nazir lembaga dan 5 pakar wakaf, dengan rentang waktu penelitian mulai bulan September hingga Januari 2021. Hasil analisis SWOT adalah lembaga wakaf perlu melakukan strategi WT (Weakness Threats), yaitu strategi defensif. Sementara itu, analisis QSPM menemukan bahwa strategi kedua adalah yang paling diprioritaskan. Pada akhir penelitian ini, hasil dari penelitian-penelitian tersebut serta rekomendasinya akan dibahas lebih lanjut.
\end{abstract}

Kata kunci: Nazir wakaf, pengembangan, QSPM, SWOT.

\section{INTRODUCTION}

Waqf is one of the Islamic financial instruments that are very distinctive and has a great potential for solving social issues in society, such as poverty and income inequality. Waqf's function is not limited to worship; it is also intended to address four key areas, including education, health, social services, and the development of SMEs (Small and Medium Enterprises) (Zahro' et al., 2020).

Currently, Islamist nations such as Saudi Arabia and Turkey have made it a state policy. This commitment is shown in the establishment of a waqf ministry tasked with the responsibility of administering not just waqf assets and mauquf'alaih, but also nazir waqf, the pioneer of waqf success. The primary aim to increase waqf benefits is through productive waqf practices, such as those in the sector of modern business property. Following that, scholarships are awarded to enhance intellectual quality (Nur, 2019). Additionally, Singapore's waqf practice garners attention since, while being a Muslim minority country, its Nazirites are permitted to engage in istibdal, or the practice of shifting waqf assets to increase the benefits (Aziz, 2017; Pertiwi et al., 2019).

Moreover, the success of waqf may be traced back to the early era of Islam, since the Rasulullah era, Khulafaur-Rashidin, Umayyah dynasty, Abbasiyah dynasty, and Turki Usmani dynasty were all 
predecessors. The point to emphasize in their administration is to preclude treating waqf property as private property, even if it has been waqf. Waqf properties are not inheritable. The managers are extremely committed to upholding the trust. If he is unable to fulfill the mandate, he is not compelled to continue using the waqf property, but is transferred to the Baitul Mal, which has complete jurisdiction over the property (Kasdi, 2013; Noviyanti, 2016). Additionally, waqf recording, waqf certification, and others were initiated at that time, all in accordance with the applicable legislation (Direktorat Jenderal Pemberdayaan Wakaf, 2006).

In Indonesia, waqf content is increasingly gaining popularity, accompanied by an increase in waqf institutions. However, the real waqf practice in Indonesia is still far from what is intended. According to BWI, there are already 285 registered Nazir in Indonesia's cash waqf institutions as of June 2021. Meanwhile, according to the 2019 Siwak Ministry of Religion, the total number of Nazir in Indonesia is projected to be approximately 395 thousand, with individual Nazir outnumbering institutions and organizations. Additionally, the management is around 72.79 percent, indicating that it is geared toward worship in mosques and musalla.

Followed by schools and other social activities accounting for 19.28 percent (Siwak Ministry of Religious Affairs Indonesia, 2020). This study attempts to highlight on one of Indonesia's most popular regions, North Sumatra. This area has 72.981 kilometers and is populated by 14.56 million people. This one was selected because it is well-known to many people, to various cultures and religions both inside and outside of Indonesia. Origin cultures such as Batak, Mandailing, and Karo may coexist peacefully with Aceh, Minang, Javanese, Kalimantan, Sulawesi, Papua, India, China and so on. North Sumatra has a huge population of Nazir, estimated to be approximately 16,295. However, this figure is heavily skewed toward mosque/individual-based nazir. No legal form of waqf or productive waqf has been discovered. In addition, on Table 1 could be seen that the waqf land of North Sumatera is the largest, comprising around 8,223,16 hectares (see Table 1), although the Muslim citizen is relatively small compared to other regions (8.579.830 out of 207 million Muslims in Indonesia, according to Statistic Indonesia).

Table 1. Top seven waqf lands in Indonesian provinces

\begin{tabular}{clcclc}
\hline No & Name Provinces & $\begin{array}{c}\text { Amount } \\
\text { (Location) }\end{array}$ & No & $\begin{array}{c}\text { Name of } \\
\text { Provinces }\end{array}$ & $\begin{array}{c}\text { Length } \\
\text { (Hectares) }\end{array}$ \\
\hline 1 & Central Java & 99,390 & 1 & North Sumatera & $8,223.16$ \\
2 & West Java & 72,117 & 2 & Aceh & 7,674 \\
3 & East Java & 66,291 & 3 & Lampung & $5,640.19$ \\
4 & Banten & 15,416 & 4 & West Java & $5,075.01$ \\
5 & Aceh & 13,984 & 5 & Central Java & $5,073.7$ \\
6 & Lampung & 12,761 & 6 & East Java & $4,362.02$ \\
7 & North Sumatera & 10,857 & 7 & Riau & $2,096.61$ \\
\hline
\end{tabular}

Source: Siwak Kemenag, 2019.

Unfortunately, this study does not observe the number, but the nazir has adopted the implementation. According to Article 11 of Law No. 41, nazir is responsible for administering waqf assets; managing and developing waqf property in line with its purpose, function, and designation; monitoring and protecting the waqf property; and reporting to BWI on the progress of duties. We divide them into three categories, each of which should be addressed in regard to nazir issues. First, its organization. Nazir was selected among the people only on the basis of his beliefs, kinship or status, and even inheritance, without regard for his skill in administering waqf assets. As a result, the dominance of individual managers over corporate nazir remains (Ali et al., 2018; Baharuddin \& Iman, 2018; Firdaus et al., 2019). Thera are also some assumptions that the nazir profession is voluntary and treated as a side job rather than the primary job (Huda et al., 2017). 
Second, its human resources, which include the recruitment of inept, old, and light-hearted individuals (Arifin, 2014). Nazir retains a conventional mindset and is reluctant to becoming productive. While others profess to make it useful, they sometimes abuse it for their own personal gain by renting/selling to third parties with inappropriate procedures (Baharuddin \& Iman, 2018; Syukron, 2012).

Third, its management is related to conventional waqf assets empowerment (Syukron, 2012). Whereas the waqf management is required to be professionally managed by the waqif or candidate by adhering to transparency, general accountability, operational standards, and efficiency (Ilyas, 2017). Additionally, nazir's performance of his tasks should be independent of unilateral or external interests (Ridwan, 2012). Nazir currently does not comprehend waqf, has a low level of commitment, and is less than optimal in adhering to nazir's code of ethics. The government, Islamic institutions, and organizations have only followed nazir's guidance to a limited extent (Baharuddin \& Iman, 2018; Firdaus et al., 2019).

This study has implications for academics as waqf observers, waqf practitioners who can learn about Nazir's conditions on the ground and come up with alternative approaches to solving them, as well as policymakers such as the BWI, the Ministry of Religion, and local governments who can incorporate the findings of this study into their decision-making processes in order to achieve the vision and mission of advancing economic civilization among people through waqf. Thus, this research advises on the most appropriate strategy from a number of alternative priority strategies that should be adopted and on which priority strategies should be implemented first.

\section{LITERATURE REVIEW}

\section{Background Theory}

The term of nazir is linguistically derived from the Arabic word of hafiz, which means guard (Manzur, 1996). Another term for nazir is mutawalli. Nazir is a term that refers to an individual or group of people who are responsible for taking care, managing, maintaining, and developing waqf assets (Hasan, 2011). Nazir does not have absolute power over the waqf assets entrusted to him, even though his position is important in waqf assets. Nazir is only administering it to ensure that waqf assets are used in accordance with the wishes of waqif. Nazir as stated by the Direktorat Jenderal Pemberdayaan Wakaf Ministry of Religious Affairs Indonesia can employ representatives or assistants to carry out their duties and responsibilities in managing waqf assets.

Based on the Indonesian constitution number 41 of 2004 article 9, there are three types of waqf nazir in Indonesia: individual nazir, organizational nazir and incorporated nazir. In general, they should meet the requirements of being Muslim, mature, and capable of legal action. Moreover, additional criteria are classified into three categories: moral, managerial, and business. The duties and obligations of nazir, in the perspective of Imam Nawawi in general, are to preserve waqf assets, safeguard their benefit, develop their benefit, and distribute the profits of the waqf assets to those who are entitled. In the same constitution, articles 12 and 13, it is also explained that nazir can receive a reward from the net proceeds from the management and development of waqf assets up to ten percent. Also, nazir is entitled to receive guidance from the Ministry of Religious Affairs Indonesia and BWI (Badan Wakaf Indonesia). Then, in article 11, nazir's duties are divided into several parts, including administering waqf assets; managing and developing waqf assets in accordance with their purpose, function, and allotment; supervising and protecting waqf property; reporting to the BWI on task implementation.

Human resource is one of the main factors which determine how an institution or organization will develop in the future. Human resource development is an effort that aims to improve employee skills through education, training and final development that will be useful later to carry out duties as employees and have a long-term cycle (Mathis \& Jackson, 2002). The components that should be 
noticed are competencies, the right placement, clear authority, responsibility, trust, encouragement, leadership, and motivation. Creativity, innovation, synergy, and giving of responsibility become strategies to improve worker performance (Priyono \& Marnis, 2008). Training is implemented into two steps: on-the-job training through internships, job instruction training, coaching, job rotation, and apprenticeship, etc, and off-the-job training through simulation and presentation techniques (Handoko, 2000; Hariandja, 2009; Yuli, 2005).

To attain professionalism, an employee must take into account many factors, including specific skill education, legality, the standard of performance, discipline, research, attitude, main income, responsibility, and community of the same profession (Nur, 1995).

Nazir should pay attention to these areas: 1) Maslahah (gaining benefits/avoiding harm) which means the nazir must prioritize maslahah aspects, as a form of responsibility in providing optimal benefits for mauquf 'alaih; 2) Transparency, in which the nazir must manage waqf assets or cash waqf in a transparent manner and under good governance, producing regular performance and financial reports that that are accessible to waqif. This is also the main characteristic that a leader must possess. The transparency in leadership transparency must be a tradition in order to cover up acts of dishonesty, corruption, manipulation, and so forth; 3) Productivity, in which nazir must be able to manage waqf funds productively so that mauquf 'alaih will be able to maintain waqf assets/cash waqf on sustainable productivity in terms of the quantity of work, quality of work and timeliness; 4) Trustworthiness, in which nazir's integrity is very important and they must avoid risky business opportunities and must be based on fundamental Islamic rules; and 5) Sustainability, in which the nazir must be able to maintain the sustainability of the value of waqf assets. Moreover, other aspects that should be addressed include public accountability, which is a method of implementing trust and shiddiq/honesty, as well as aspirational (willing to listen to and accommodate all the dynamics of the institution of nazir), in which a trusted nazir must encourage a social system that involves the participation of many groups to prevent unilateral decision-making patterns by the elite parties (BI et al., 2018, p. 9; Direktorat Jenderal Pemberdayaan Wakaf, 2013).

\section{Previous Studies}

In selecting on the topic of this research, we analyzed numerous prior study approaches on waqf that employed descriptive qualitative rather than SWOT and QSPM analysis, which were not available in Scopus international publications during our literature search. In the paper entitled The SWOT Analysis of Waqf Governance in Brunei Darussalam, the results were summarized into four parts: 1) Strength: benefits from the majority of Muslims in Brunei, facilitating revenue generation for MUIB and the Tanmiyah Body. Large waqf that will benefit Muslims in the future, as well as property waqf and direct financial aid from the government. 2) Weaknesses: the lack of exploration on waqf potentials, issues with human resources and management, as well as the slow growth of waqf compared to neighboring countries. 3) Opportunities: the great potential of cash waqf and land waqf. 4) Threats: the donors' lack of awareness and understanding, limited natural resources, as well as the limited fatwa regarding istibdal and the controversy over the cash waqf (Bakar et al., 2020).

Another research finding recognized the highest-ranking of threats: the relatively weak political will of the authorities, followed by the majority of traditional nazir (Rusydiana \& Rahayu, 2019). Other studies confirm that the implementation of nazir guidance was ineffective and the pledge of waqf was only verbal (Putri, 2016). Nazir must have three social entrepreneur competencies: knowledge, skills, and attitude (Furqon, 2016).

Abdullah (2020) demonstrated the findings in his journal article entitled Islamic Endowment (Waqf) in India: Towards Poverty Reduction of Muslims in the Country using a qualitative method (sociolegal approach) that waqf institutions in India have large financial resources and infrastructure, and their role can reduce poverty. Unfortunately, the lack of a strong governance structure, rigidity in wrong approaches and applications triggered by political reluctance has resulted in the institution of 
waqf having little impacts on society.

Furthermore, it is found that there is a lack of competent human resources, inadequate infrastructure, weak governance mechanisms, corruption, insufficient use of technology, and a lack of social awareness, and so on (Islam, 2018). The main problem for management is public awareness, followed by human resource development. Whereas from a public point of view, lack of material assets and lack of knowledge are the main obstacles in creating waqf assets. Besides, there are three kinds of problems that can be detected: development, management, and public awareness (Haji-Mohiddin, Hajah, Mas, 2015).

\section{METHOD}

This paper utilizes a descriptive qualitative approach is to describe a phenomenon and its characteristics with what rather than how or why something has happened (Nassaji, 2015). Meanwhile, in this qualitative research, we used SWOT and QSPM analysis to determine which strategies should be implemented for waqf management. SWOT analysis is defined as a systematic identification of various factors to formulate a company strategy (Rangkuti, 2017). Then, QSPM is a tool used to determine attractive relativeness of the implementation of alternative strategies, which are used in stage 3 of the formulation strategy analysis framework (Umar, 2008). QSPM may reduce the risk of overlooking or overweighting key factors in a company, while also improving the probability that the final decision reached is in the best interests of the company. (Wicaksono, 2015).

By using many interviews with some experts and a two-step questionnaire, the respondents should fill out the questionnaire by determining the assessment criteria (Likert scale) for evaluating internal and external factors as follows: assessment of current condition on a scale of 1 to 6 and the urgency of fulfillment on a scale of 1 to 4 (Rangkuti, 2017); and in QSPM, the attractiveness was assigned a value between 1 and 4 (Umar, 2008).

Furthermore, to determine the position of the EFE and IFE matrices, their values are calculated on the $\mathrm{X}$-axis (Total value of the strength-Total value of weakness) and Y-axis (Total value of the opportunity-Total value of threat). It is located into 5 quadrants: quadrant I (positive, positive) represents a progressive strategy, quadrant II (positive, negative) indicates diversification strategy, quadrant III (negative, positive) indicates turnaround-style strategy, and quadrant IV (negative, negative) means defensive strategy (Rangkuti, 2017).

After finding the strategic position, the questionnaire is developed based on the response of the respondents and discussion with experts to formulate some alternative strategies. Therefore, as previously mentioned, the respondents fill the weight/attractiveness score. These weights are calculated to find the total attractiveness score (TAS). Finally, the TAS with the greatest score is the most priority strategy that should be implemented (Umar, 2008).

\section{RESULTS AND DISCUSSION}

\section{Results}

The data are obtained from the interview and the questionnaire was completed by 8 respondents for SWOT and 5 respondents for QSPM between September and January 2021. Respondents were selected based on their understanding of waqf, especially concerning the development of waqf nazir, both from academics and practitioners. The selection of respondents was taken from representatives of large waqf institutions in North Sumatra, including the head of BWI of North Sumatera, the head of the zakat and waqf empowerment, the Ministry of Religious Affairs Indonesia in North Sumatera, the head of waqf Islamic State University of North Sumatera, the daily chairman of the Al-Khairiyah Delitua Waqf Foundation, the secretary of the Al-Kaffah Binjai waqf Foundation, the secretary of the 
North Sumatera Nazir Forum, the general Secretary of Ar-Raudlatul Hasanah Boarding School and the deputy chairman of the Muhammadiyah North Sumatra Regional Leadership.

Especially for QSPM, the respondents should understand and focus on waqf and nazir development, or we may refer to them as waqf specialists in North Sumatra. In addition, Nazir in North Sumatera is still dominated by individual nazir around 16,000 people and are dominated by small nazir of mosque. In choosing respondents, we decide that the respondents are only from the institutional and organizational nazir in North Sumatra. Even though the fact of the number of institutional and organizational nazir remains unknown due to the fact that some of them do not report to the representative of the Indonesian Waqf Board in North Sumatera, it did not break our curiosity to see the waqf condition in this area. In some seminars on waqf, many experts said that most of Indonesian people still do not believe on waqf practice especially productive waqf. As a result, we attempt to investigate it by distributing questionnaires and conducting some interviews with the respondents. Detailed information about the respondents and interviewers can be found in Appendix.

\section{Analysis}

\section{SWOT Analysis}

To conduct a SWOT analysis, we first discuss with the primary expert, Hendri Tanjung, a renowned specialist on nazir, to validate the questionnaires that will be distributed to respondents. We provided some generalized data and correlated it with strength, weakness, opportunity, and threat indicators. The expert critiqued our points by agreeing or disagreeing with specific reasons. After many discussions, we developed the final questionnaires to share with respondents. Moreover, we conducted some interviews in a few locations.

After collecting questionnaires from respondents, we were able to determine how respondents carry out the waqf management in Indonesia in terms of strengths, weaknesses, opportunities, and threats. During data collection, we had listed around 10 respondents to fill SWOT questionnaire, but because of their status as private nazir who had just converted to institutional nazir, they declined to fill the questionnaires. As a result, we choose only the serious nazirs who are capable of explaining their situation transparently.

In calculating all of those indicators, the researchers add up all of the input numbers for each item (1-6 and 1-4) using Microsoft Excel software. Finally, Table 2 and Table 3 provide the illustration of IFE and EFE matrices. The IFE strategy matrix may be used to discover and evaluate the relationship between the company's primary strengths and weaknesses. Meanwhile, the EFE strategy matrix helps strategists to summarize and evaluate economic, social, cultural, demographic, environmental, political, government, legal, and competitive information (Wicaksono, 2015).

From Table 2, it was found that the total number of scales is divided by the number of respondents. In the strength column of item 1 , we can see the calculation of the average scale $(40 / 8=5)$. Furthermore, the result of values is calculated by the average scale divided by the total scale. In the same column, the rating can be calculated $(5.00 / 48.63=0.103)$. Thus, after finding the results of each item, all the rating results are added and the average result must be equal to one. This process is also displayed in Table 3. 
Table 2 Internal factor evaluation matrix

\begin{tabular}{|c|c|c|c|c|c|}
\hline & Strength Indicators & Scale & Value & Rating & Score \\
\hline 1 & $\begin{array}{l}\text { The legal constitution for nazir is quite } \\
\text { clear }\end{array}$ & 5.00 & 0.103 & 3.00 & 0.308 \\
\hline 2 & Jazir obey religious orders & 4.00 & 0.082 & 3.13 & 0.257 \\
\hline 3 & Nazir is discipline & 3.88 & 0.080 & 3.50 & .279 \\
\hline 4 & $\begin{array}{l}\text { Nazir is responsible, hardworking \& } \\
\text { honest }\end{array}$ & 4.13 & 0.085 & 3.25 & 0.276 \\
\hline 5 & Nazir has communication skills & 4.75 & 0.098 & 2.75 & 0.269 \\
\hline 6 & Nazi & 4.38 & 090 & 3.25 & 0.292 \\
\hline 7 & Nazir has organizational experience & 4.63 & 0.095 & 2.38 & 0.226 \\
\hline 8 & $\begin{array}{l}\text { Nazir can create interpersonal } \\
\text { relationships }\end{array}$ & 4.00 & 0.082 & 3.00 & 0.247 \\
\hline 9 & $\begin{array}{l}\text { Nazir has a minimum education of } \\
\text { Islamic boarding or high school }\end{array}$ & 5.63 & 0.116 & 2.38 & 0.275 \\
\hline 10 & Nazir can solve problems & 4.13 & 0.085 & 2.88 & 0.244 \\
\hline \multirow[t]{3}{*}{11} & $\begin{array}{l}\text { Nazir upholds maqasid sharia in waqf } \\
\text { empowerment }\end{array}$ & 4.13 & 0.085 & 2.88 & 0.244 \\
\hline & Total & 48.63 & 1 & & 2.916 \\
\hline & Weakness Ind & Scale & Value & Rating & Score \\
\hline 1 & $\begin{array}{l}\text { Nazir recruitment is often based on } \\
\text { kinship/belief }\end{array}$ & 4.13 & 0.085 & 2.88 & 0.245 \\
\hline 2 & Nazir is dominated by elderly people & 4.13 & 0.085 & 3.00 & 0.255 \\
\hline 3 & $\begin{array}{l}\text { It is difficult to collaborate between } \\
\text { nazir }\end{array}$ & 3.63 & 0.075 & 2.88 & 0.215 \\
\hline 4 & $\begin{array}{l}\text { Nazir data per category are not yet } \\
\text { collective and updated }\end{array}$ & 3.50 & 0.072 & 2.88 & 0.207 \\
\hline 5 & $\begin{array}{l}\text { Lack of reporting of resign/passed } \\
\text { away nazir }\end{array}$ & 3.50 & 0.072 & 3.00 & 0.216 \\
\hline 6 & $\begin{array}{l}\text { Nazir does not have sufficient } \\
\text { skills/talents }\end{array}$ & 3.50 & 0.072 & 2.75 & 0.198 \\
\hline 7 & Most nazir are still clueless & 3.75 & 0.077 & 3.25 & 0.251 \\
\hline 8 & $\begin{array}{l}\text { Nazir still manages waqf in a } \\
\text { conventional management pattern }\end{array}$ & 3.75 & 0.077 & 3.00 & 0.232 \\
\hline 9 & $\begin{array}{l}\text { The division of each duty and } \\
\text { responsibilities are still not optimal }\end{array}$ & 3.88 & 0.080 & 3.00 & 0.240 \\
\hline 10 & & 3.38 & & & 0.217 \\
\hline 11 & $\begin{array}{l}\text { The difficulty of training new and old } \\
\text { nazir }\end{array}$ & 3.88 & 0.080 & 3.50 & 0.280 \\
\hline 12 & $\begin{array}{l}\text { The rewards/salaries given to nazir are } \\
\text { not satisfactory }\end{array}$ & 4.00 & 0.082 & 3.38 & 0.278 \\
\hline 13 & $\begin{array}{l}\text { There is no special budget for nazir's } \\
\text { empowerment from the government }\end{array}$ & 3.50 & 0.072 & 3.63 & 0.262 \\
\hline
\end{tabular}


Table 3 External factor evaluation matrix

\begin{tabular}{|c|c|c|c|c|c|}
\hline & Opportunity Indicators & Scale & Value & Rating & Score \\
\hline 1 & Awareness of waqf increased & 4.50 & 0.153 & 3.13 & 0.477 \\
\hline 2 & The community's desire for waqf & 3.88 & 0.131 & 3.00 & 0.394 \\
\hline 3 & $\begin{array}{l}\text { Indonesia is given the title as a generous country } \\
\text { in the international world }\end{array}$ & 4.63 & 0.157 & 2.75 & 0.431 \\
\hline 4 & $\begin{array}{l}\text { The number of nazir waqf } \\
\text { organizations/institutions continue to grow up }\end{array}$ & 4.75 & 0.161 & 3.00 & 0.483 \\
\hline 5 & $\begin{array}{l}\text { Collaboration between domestic and foreign } \\
\text { nazir expand the area of waqf management }\end{array}$ & 3.63 & 0.123 & 2.88 & 0.353 \\
\hline 6 & $\begin{array}{l}\text { The synergy of waqf institutions using the } \\
\text { crowdfunding concept }\end{array}$ & 3.38 & 0.114 & 2.75 & 0.315 \\
\hline \multirow[t]{3}{*}{7} & The character/figure matter of nazir & 4.75 & 0.161 & 2.75 & 0.443 \\
\hline & Total & 29.50 & 1 & & 2.896 \\
\hline & Threat Indicators & Scale & Value & Rating & Score \\
\hline 1 & Wrong understanding of waqf & 3.50 & 0.311 & 2.88 & 0.894 \\
\hline 2 & Global economic recession & 3.75 & 0.333 & 3.25 & 1.083 \\
\hline \multirow[t]{2}{*}{3} & $\begin{array}{l}\text { Decrease in people's income due to the } \\
\text { pandemic }\end{array}$ & 4.00 & 0.356 & 3.38 & 1.200 \\
\hline & Total & 11.25 & 1 & & 3.178 \\
\hline
\end{tabular}

The following is the final result of the IFE (Internal Factor Evaluation) and EFE (External Factor Evaluation) calculations:

IFE Score (Strength Score - Weakness Score) $\quad=2.916-3.097=\mathbf{- 0 . 1 8 1}$

EFE Score (Chance - Threat Score) $\quad=2.896-3.178=\mathbf{- 0 . 2 8 2}$

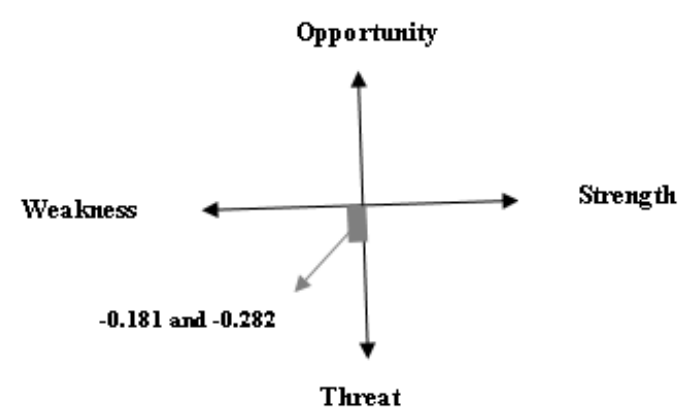

Figure 1 The positioning of SWOT analysis result

\section{QSPM Analysis}

This procedure is begun with an examination of the results of the SWOT analysis. As previously mentioned, the result is a defensive strategy. Therefore, we had a discussion with some experts such as Hendri Tanjung, as a representative expert of Indonesia, and Saparuddin, as a representative expert of North Sumatera, to re-check the QSPM questionnaires. Then they were asked to fill the questionnaire. Similar to the SWOT respondents, it is difficult to locate particular experts focus on nazir because few experts have passed away and are of elderly. As a result, they were unable to complete the questionnaires and could only provide responses during the interview. The information of respondents could be seen in Appendix.

The QSPM matrix is used to evaluate alternative strategies through objective and intuitive evaluations of respondents based on key success factors. The alternative strategy in the QSPM matrix is generated from the WT strategy of SWOT analysis.

This alternate strategy is analyzed for its influence on internal factors (strengths and weaknesses) and external factors (opportunities and threats). In the process of filling out the QSPM matrix, we conducted interviews and re-discussed with respondents who have skills and knowledge related to the 
development of nazir in North Sumatra. In addition, Attractiveness Score is assigned to each strategy in order to show the relation of one strategy to another. Then, at the end, we focus on the total attractiveness score to determine the largest result.

\section{Discussion}

\section{Current strategy implemented by nazir in North Sumatra}

According to the data provided in the SWOT analysis, the strategy implemented in North Sumatra is in a defensive status, which means to minimize weaknesses and avoid threats. If we reflect on the past, actually the term waqf has really been a common phrase since the time of the Prophet Muhammad. His companions and the followers have entrusted their possessions to Allah for the sake of waqf. Therefore, waqf institutions should have no difficulty increasing the amount of the waqf fund collection. Otherwise, Indonesia, like North Sumatra, is confronted with the same problem. The challenges stated by Nur Syam on Republika News in 2018 are data validation of waqf assets, increasing the collection of cash waqf, certification of waqf land, the use of waqf assets for productive economic activities and social welfare, then the capacity and sense of responsibility of the nazir.

Furthermore, the current strategy adopted by North Sumatra is as follows. First, in terms of organization, the current recruitment strategy, according to some respondents, is structurally appropriate based on the problem identification related to kinship and community persuasion. Competence is still not a high priority. Nazir in North Sumatra is still dominated by individual nazir. The database of nazir institutions/organizations does not currently offer this information.

Second, the strategy in appointing nazir is justified by the waqf institution, which is built on trust, and the majority of those appointed are above the age of 60. According to Firdaus (2020) in the interview, age is not a significant disadvantage as long as nazir knows how to manage waqf. However, indeed the training and coaching activities so far have not been carried out seriously or just in moderation. According to Pohan (2020) as an interviewee, the activities conducted so far have mostly been training activities with a very small number of nazir. It is only around 100 people per year from a total of 16 thousand for individual nazir. There is no clear number yet for incorporated nazir and organizational nazir. So, they do not equally get the provision of knowledge. Next, nazir's old age really cannot show a significant increase in the development of waqf due to poor absorption of knowledge.

The head of BWI of North Sumatra even confirms that the training activities themselves are sometimes accompanied by other intentions, like an opportunity to travel to Medan for residents outside Medan, which is a big capital city, as well as the elderly who do not understand the fiqh of waqf. Of course, this condition is very concerning because the results obtained from training/sharing knowledge with nazir are meaningless.

Based on the argument of Hendri Tanjung, nowadays, the great efforts of BWI in Jakarta are also quite large. BWI members have planned to encourage especially for many individual nazir in working together and creating institutional nazir. However, as coaching efforts are carried out in the field, the characteristic of nazir which is influenced by culture and the environment sometimes prevents this goal from being attained optimally.

Furthermore, according to the head of BWI of North Sumatra, their team has taken over cash waqf assets of around 217 million Rupiah from the North Sumatra Waqf Board, which was established in 2003, before the arrival of the BWI representative. Then, it is supplemented with cash accounts from BWI, which has generated quite good results. The total amount collected has reached 400 million rupiah, with a profit around 150 million rupiah. The benefits have also been distributed to several places in 2020, including the transfer of approximately 50 million rupiah to the Covid-19 medical sector, the construction of the Kapten Muslim's mosque, the waqf land dispute budget, and the 
education fund budget for school children who are truly poor and incapable, as well as the budget for empowering nazir. However, in reality, a single moving institution is insufficient. Therefore, it is necessary to operate waqf management effectively and to work together to improve waqf products.

Third, academic respondents said that the systematical structure of nazir have an impact on how to build relationships with others. Whether harmonious or not, nazir institutions are rarely dealing with conflicts. However, for individual nazir, disharmony often occurs because of their perception of waqf ownership. As a result, it is often discovered that nazir is untrustworthy and does not constantly adhere to the rules.

According to Mohiddin (2015), the problem of waqf always stands on lacking human resource development strategies, weak management and low community awareness, as North Sumatra experienced. Efforts with the implementation of an internal control system are certainly needed to support the organization in achieving its goals, by mitigating risk, complying with organizational rules and policies.

\section{Internal and external factors in North Sumatra and its urgent fulfillment}

Table 4 Ranking of assessment and urgent fulfillment

\begin{tabular}{|c|c|c|}
\hline \multirow[b]{2}{*}{ No } & \multicolumn{2}{|c|}{ INTERNAL FACTORS } \\
\hline & $\begin{array}{l}\text { The Assessment of the Current Conditions } \\
\text { (Strength) }\end{array}$ & The Urgency of Fulfillment (Strength) \\
\hline 1 & $\begin{array}{l}\text { Nazir has a minimum education of an Islamic } \\
\text { boarding/ high school }\end{array}$ & Nazir is disciplined \\
\hline 2 & $\begin{array}{l}\text { The legality of the constitution for nazir is } \\
\text { quite clear }\end{array}$ & $\begin{array}{l}\text { Nazir is responsible, hardworking and } \\
\text { honest }\end{array}$ \\
\hline 3 & Nazir has communication skills & Nazir knows sharing knowledge \\
\hline 4 & Nazir has organizational experience & Nazir obey the religious orders \\
\hline \multirow[t]{2}{*}{5} & Nazir knows sharing knowledge & $\begin{array}{l}\text { The legality of the constitution for nazir } \\
\text { is quite clear }\end{array}$ \\
\hline & $\begin{array}{l}\text { The Assessment of the Current Conditions } \\
\text { (Weakness) }\end{array}$ & $\begin{array}{l}\text { The Urgency of Fulfillment } \\
\text { (Weakness) }\end{array}$ \\
\hline 1 & $\begin{array}{l}\text { Nazir's recruitment is often based on } \\
\text { kinship/trust }\end{array}$ & $\begin{array}{l}\text { There is no special budget for Nazir's } \\
\text { empowerment from the government }\end{array}$ \\
\hline 2 & Nazir is dominated by elderly people & $\begin{array}{l}\text { The difficulty of training new and old } \\
\text { nazir }\end{array}$ \\
\hline 3 & $\begin{array}{l}\text { The rewards/salaries given to nazir are not } \\
\text { satisfactory }\end{array}$ & $\begin{array}{l}\text { The rewards / salaries given to nazir are } \\
\text { not satisfactory }\end{array}$ \\
\hline 4 & $\begin{array}{l}\text { The division of duties and responsibilities for } \\
\text { each is less than optimal }\end{array}$ & Most nazir is still clueless \\
\hline \multirow[t]{3}{*}{5} & The difficulty of training new and old nazir & Less optimal monitoring of nazir \\
\hline & \multicolumn{2}{|c|}{ EXTERNAL FACTORS } \\
\hline & $\begin{array}{l}\text { The Assessment of Current Conditions } \\
\text { (Opportunity) }\end{array}$ & $\begin{array}{l}\text { The Urgency of Fulfillment } \\
\text { (Opportunity) }\end{array}$ \\
\hline 1 & $\begin{array}{l}\text { The number of nazir organizations/ } \\
\text { institutions always grow }\end{array}$ & Awareness of waqf increased \\
\hline 2 & The element of characteristic of nazir & People's desire for waqf \\
\hline 3 & $\begin{array}{l}\text { Indonesia is given the title of a generous } \\
\text { country in the international world }\end{array}$ & $\begin{array}{l}\text { The number of nazir } \\
\text { organizations/institutions always grow }\end{array}$ \\
\hline \multirow[t]{2}{*}{4} & Awareness of waqf increased & $\begin{array}{l}\text { Collaboration between domestic and } \\
\text { foreign nazir to expand the area of waqf } \\
\text { management }\end{array}$ \\
\hline & $\begin{array}{l}\text { The Assessment of Current Conditions } \\
\text { (Threat) }\end{array}$ & The Urgency of Fulfillment (Threat) \\
\hline 1 & $\begin{array}{l}\text { The decline in community income due to the } \\
\text { pandemic }\end{array}$ & $\begin{array}{l}\text { The decline in community income due to } \\
\text { the pandemic }\end{array}$ \\
\hline 2 & There is a global economic recession & There is a global economic recession \\
\hline 3 & Wrong understanding of waqf & Wrong understanding of waqf \\
\hline
\end{tabular}


Table 4 illustrates some important points to consider. Those factors are sorted based on the results of the respondent's marking scale 1-6 for the assessment of current condition and 1-4 for the urgency of handling.

\section{The main priority strategy}

After processing the data in SWOT analysis, six priority strategies are presented as follow:

1. To regenerate waqf nazir and provide opportunities for young people with the potentials to empower waqf.

2. To improve the competence of the nazir and the division of their duties, according to their respective fields of competence.

3. To encourage local governments to allocate waqf funds for empowering nazir.

4. To enable people to have waqf in small digits, which is further promoted through online certificates as proof of waqf.

5. To provide a decent portion of salary to nazir according to his competence so that later he can work optimally.

6. To encourage waqf literacy sustainably in terms of understanding and implementation, beginning with early childhood education.

Hence, it can be stated that the main priority strategy that needs to be implemented in North Sumatra is to improve the quality of nazir by honing their skill competence in-depth and arranging the division of tasks according to their respective competency fields.

Professional nazir must be qualified in the scope of human skills, human technologies and human relations. Human skill is related to the mandate in developing waqf. It has a good reputation and moral credibility. Not only should one be versed in Islamic sciences pertaining to waqf, but also in economics. So that, productive waqf be fulfilled to its full potential. Meanwhile, human technology is related to the ability to manage waqf assets with transparency. This principle requires the timely dissemination of accurate, sufficient and comparable information. In addition to this, it is concerned with preventing unwanted dominance by stakeholders. For human relations, nazir must be able to build a network for the benefit of waqf management and development. The collaboration is administered by third parties in the form of partnerships based on mutual benefits such as investment, opening a business entity, and others.

The waqf authorities have to upgrade nazir to be more attractive. For example, according to Firdaus' (2020) statement, seminars on waqf are initiated by a young committee by inviting young and old people and sponsored directly by other waqf institutions and local government at once. Afterward, the speakers are taken from academics such as lecturers from inside or outside the region. To minimize the budget, teleconferences can also be held in classrooms.

The Ministry of Religious Affairs indeed provides 100 million rupiah per year to BWI North Sumatra, and there is also a local government fund for specific area such as Medan, which is according to the head of BWI Medan, amounts to approximately 300 million Rupiah and is not regularly distributed once a year. However, the benefit for nazir is not yet greater. In fact, since the Covid-19 pandemic, it has been unclear when waqf payments from the local government would be distributed.

\section{CONCLUSION}

\section{Conclusion}

Currently, the strategy of developing nazir through training and coaching still requires refinement due to certain concerns about nazir's lack of capacity. As detailed in the table of important handling, the most urgent issue is to resolve their skill competency and refocus them on their job desk. Nazir's job is not voluntary, but it may lead to a future profession. Later, the other problem to be resolved is the 
budget and encouragement from the authority. Then, based on the SWOT analysis, the current conditions experienced by waqf institutions is classified as being in the fourth quadrant. The right strategy to do is the WT (Weakness-threat) strategy, meaning that the waqf institution is in a defensive condition, requiring the waqf institution to address existing internal weakness elements in order to prevent and minimize threats. This threat can be mitigated by continuing to educate the community through seminars, training, and other means.

Finally, QSPM result indicate and highlight the main priority strategy that needs to be implemented in North Sumatra, that is to improve the quality of nazir by fostering better competence and determining the division of tasks based on their respective competency areas.

\section{Recommendation}

This paper has proved and demonstrated that nazir's development is very important to accomplish. Thus, we attempt to give new knowledge and suggestions. In addition, nazir is expected to improve the quality of its waqf management rather than the quantity, and to take a serious approach to managing productive waqf, not just for consumptive purposes (waqf through money), as has been done thus far, so that people can feel more confident in entrusting their wealth to the right nazir in God's way. Meanwhile, waqif need to be careful in selecting a nazir they can trust to manage waqf assets, as well as considering the nazir's competency in handling waqf assets. It is recommended that the waqif should engage with authorities such as BWI to ensure that there will be no future disputes after he dies. Provincial BWI is required to strengthen connections with the community by hosting engaging activities in a variety of locations, including campuses, mosques, marketplaces, and other public spaces, with the assistance of local government and advanced national waqf institutions. to raise public awareness of waqf in order to familiarize them with the notion of productive waqf and to create opportunities for the community to participate in the management of productive lands as employees assisting nazir. Finally, government officials are expected to fully support waqf implementation because it has the potential to assist the government in reducing poverty.

\section{REFERENCES}

Abdullah, M. (2020). Islamic Endowment (Waqf) in India: Towards Poverty Reduction of Muslims in the Country. Journal of Research in Emerging Markets, 2(2), 48-60. https://doi.org/10.30585/jrems.v2i2.482.

Ali, K. M., Yuliani, M., Mulatsih, S., \& Abdullah, Z. (2018). Aspek-aspek prioritas manajemen wakaf di Indonesia. AL-FALAH: Journal of Islamic Economics, 3(1), 1-28. https://doi.org/10.29240/jie.v3i1.345.

Arifin, J. (2014). Problematika perwakafan di indonesia (telaah historis sosiologis). Ziswaf, 1(2), 249272.

Aziz, M. (2017). Peran Badan Wakaf Indonesia (BWI) dalam mengembangkan prospek wakaf uang di Indonesia. JES (Jurnal Ekonomi Syariah), 1(2), 188-208. https://doi.org/10.30736/jes.v1i2.15.

Baharuddin, A. Z., \& Iman, R. Q. (2018). Nazir wakaf profesional, standarisasi dan problematikanya. Li Falah: Jurnal Studi Ekonomi dan Bisnis Islam, 3(2), 62-74. http://ejournal.iainkendari.ac.id/lifalah/article/view/1197.

Bakar, M. A., Ahmad, S., Salleh, A. D., \& Salleh, M. F. M. (2020). The SWOT analysis of waqf governance in Brunei Darussalam. International Research Journal of Shariah, Muamalat and Islam, 2, 01-22. https://doi.org/10.35631/irjsmi.23001.

BI, BWI, \& IRTI-IsDB. (2018). Waqf core principles. In Islamic Social Sector Development Initiatives (Issue 1).

[BPS] Badan Pusat Statistik. (2010). Penduduk Indonesia: Hasil Sensus Penduduk 2010 [online]. Retrieved Ocotber 1, 2021, from https://www.bps.go.id/.

Direktorat Jenderal Pemberdayaan Wakaf. (2006). Fiqh Wakaf. Jakarta (ID), Kemenag. 
Direktorat Jenderal Pemberdayaan Wakaf. (2013). Strategi Pengembangan Wakaf Tunai di Indonesia. Jakarta (ID), Kementerian Agama RI.

Firdaus, N., Nuruddin, A. \& Hasmawati, F. (2019). Problematic analysis of cash waqf management in West Sumatera through Analytic Network Process (ANP) Approach. Budapest International Research and Critics Institute (BIRCI-Journal): Humanities and Social Sciences, 2(3), 285298. https://doi.org/10.33258/birci.v2i3.429.

Furqon, A. (2016). Nazir wakaf berbasis wirausaha sosial di Yayasan Muslimin Kota Pekalongan. Madinia Jurnal Kajian Islam, 20(1), 55-68.

Haji-Mohiddin, H. \& Mas, N. (2015). Waqf development in Malaysia and Singapore: A comparative study (Doctoral dissertation, Durham University, Durham, England).

Handoko, T. H. (2000). Manajemen Personalia dan Sumberdaya Manusia (2nd ed.). Yogyakarta (ID), BPFE.

Hariandja, M. T. E. (2009). Manajemen Sumber Daya Manusia. Jakarta (ID), PT. Grasindo.

Hasan, T. (2011). Pemberdayaan nazir. Al- Awqaf Jurnal Wakaf dan Ekonomi Islam, 4(11).

Huda, N., Rini, N., Mardoni, Y., Anggraini, D., \& Hudori, K. (2017). Manajemen pengelolaan wakaf di Indonesia timur. EKUITAS (Jurnal Ekonomi Dan Keuangan), 20(1), 1-17. https://doi.org/10.24034/j25485024.y2016.v20.i1.2035.

Ilyas, M. (2017). Profesionalisme nazhir wakaf dalam pemberdayaan ekonomi. Jurnal Al-Qadau: Peradilan dan Hukum Keluarga Islam, 4(1), 71-94. https://doi.org/10.24252/alqadau.v4i1.5719.

Islam, M. T. (2018). Historical development of waqf governance in Bangladesh: Challenges and prospects. Intellectual Discourse, 26, 1129-1165.

[Kemenag] Kementerian Agama. Jumlah Tanah Wakaf Seluruh Indonesia [Internet]. Retrieved October 1, 2021, from http://siwak.kemenag.go.id/tabel_jumlah_tanah_wakaf.php.

Kasdi, A. (2013). Ikhtiar pengembangan wakaf produktif: Studi analisis pemikiran Monzer Kahf tentang wakaf produktif. Equibrium, 1(2), 163-180.

Manzur, I. (1996). Lisanul 'Arab (3rd ed.). Darul Baz.

Mathis, R. L., \& Jackson, J. H. (2002). Manajement Resource: Manajemen Sumber Daya Manusia. Jakarta (ID), Salemba Empat.

Muyiddin \& Yulianto, A. (2018). Ini Enam Tantangan Perwakafan di Indonesia [online]. Retrieved January 17, 2021 from https://www.republika.co.id/berita/dunia-islam/wakaf/18/01/26/p34v393 96-ini-enam-tantangan-perwakafan-di-indonesia.

Nassaji, H. (2015). Qualitative and descriptive research: Data type versus data analysis. Language Teaching Research, 19(2), 129-132. https://doi.org/10.1177/1362168815572747.

Noviyanti, R. (2016). Pengelolaan keuangan publik Islam perspektif historis. Iqtishodia Jurnal Ekonomi Syariah, 1(1), 95-109.

Nur, A. S. (1995). Memahami Beberapa Konsep Kepemimpinan. Padang (ID), IKIP Padang.

Pertiwi, R. S., Ryandono, M. N. H. \& Rofiah, K. (2019). Regulations and management of waqf institutions in Indonesia and Singapore: A comparative study. KnE Social Sciences, 3(13), 766783. https://doi.org/10.18502/kss.v3i13.4246.

Priyono, \& Marnis. (2008). Manajemen Sumber Daya Manusia (I). Sidoarjo (ID), Zifatama Publisher.

Putri, K. S. (2016). Pembinaan Nazhir Wakaf di Kemenag Kota Padang dan BWI Sumatera Barat. UIN Sunan Kalijaga Yogyakarta.

Rangkuti, F. (2017). Teknik Membedah Kasus Bisnis Analisis SWOT (20th ed.). Jakarta (ID), PT. Gramedia Pustaka Utama.

Rusydiana, A., \& Rahayu, S. S. (2019). Bagaimana strategi pengembangan wakaf tunai di Indonesia? Jurnal Ekonomi Dan Bisnis Islam (Journal of Islamic Economics and Business), 5(1), 15. https://doi.org/10.20473/jebis.v5i1.10416.

Syukron, A. (2012). Rekonstruksi hukum Islam: Kajian historis atas urgensi pelembagaan wakaf produktif di Indonesia. Jurnal Penelitian, 8(2), 267-285. https://doi.org/10.28918/jupe.v8i2.82.

Umar, H. (2008). Strategic Management in Action. Jakarta (ID), PT. Gramedia Pustaka Utama. 
Wicaksono, W. (2015). Analisis Strategi Persaingan Perniagaan Gas Bumi (Studi Kasus PT. Perusahaan Gas Negara (Persero) Tbk SBU Distribusi Wilayah). Institut Teknologi Sepuluh Nopember.

Yuli, S. B. C. (2005). Manajemen Sumber Daya Manusia. Malang (ID), UMM Press.

Zahro', K., Jamal, M., Arroisi, J., \& Agustin, N. P. (2020). Implementasi pendistribusian wakaf tunai sebagai penunjang usaha kecil menengah di badan wakaf uang \& badan wakaf tunai MUI Yogyakarta. Ulul Albab: Jurnal Studi Dan Penelitian Hukum Islam, 3(1), 49. https://doi.org/10.30659/jua.v3i1.7554.

\section{APPENDIX}

Descriptive information of respondents and interviewees.

SWOT respondents

\begin{tabular}{|c|c|c|c|c|c|}
\hline & $\begin{array}{c}\text { Name of } \\
\text { Respondent }\end{array}$ & Affiliation & Age & Education & $\begin{array}{l}\text { Working } \\
\text { Period }\end{array}$ \\
\hline 1 & $\begin{array}{l}\text { Saparuddin } \\
\text { Siregar }\end{array}$ & $\begin{array}{l}\text { Head of waqf } \\
\text { Islamic State } \\
\text { University of North } \\
\text { Sumatra }\end{array}$ & $\begin{array}{l}57 \text { years } \\
\text { old }\end{array}$ & $\mathrm{PhD}$ & 19 years \\
\hline 2 & $\begin{array}{l}\text { Syariful } \\
\text { Mahya Bandar }\end{array}$ & $\begin{array}{l}\text { Head of BWI of } \\
\text { North Sumatra }\end{array}$ & $\begin{array}{l}67 \text { years } \\
\text { old }\end{array}$ & Master & $>2$ years \\
\hline 3 & Negara Pohan & $\begin{array}{l}\text { Head of Zakat and } \\
\text { Waqf } \\
\text { Empowerment } \\
\text { Ministry of } \\
\text { Religious Affairs } \\
\text { Indonesia in North } \\
\text { Sumatra }\end{array}$ & $\begin{array}{l}48 \text { years } \\
\text { old }\end{array}$ & Master & 23 years \\
\hline 4 & $\begin{array}{l}\text { Burhanuddin } \\
\text { Nasution }\end{array}$ & $\begin{array}{l}\text { The daily chairman } \\
\text { of the Al-Khairiyah } \\
\text { Delitua Waqf } \\
\text { Foundation }\end{array}$ & $\begin{array}{l}66 \text { years } \\
\text { old }\end{array}$ & Master & 3 years \\
\hline 5 & Nurul Hafizah & $\begin{array}{l}\text { Secretary of the Al- } \\
\text { Kaffah Binjai waqf } \\
\text { foundation }\end{array}$ & $\begin{array}{l}32 \text { years } \\
\text { old }\end{array}$ & $\begin{array}{c}\text { Bachelor } \\
\text { Degree }\end{array}$ & 14 years \\
\hline 6 & Letce Berutu & $\begin{array}{l}\text { Secretary of the } \\
\text { North Sumatra nazir } \\
\text { Forum }\end{array}$ & $\begin{array}{l}61 \text { years } \\
\text { old }\end{array}$ & Master & 10 years \\
\hline 7 & $\begin{array}{l}\text { Abdul Hakim } \\
\text { Siagian }\end{array}$ & $\begin{array}{l}\text { Deputy chairman of } \\
\text { the Muhammadiyah } \\
\text { North Sumatra } \\
\text { Regional } \\
\text { Leadership }\end{array}$ & $\begin{array}{l}55 \text { years } \\
\text { old }\end{array}$ & $\mathrm{PhD}$ & 20 years \\
\hline 8 & Miftakhuddin & $\begin{array}{l}\text { General Secretary of } \\
\text { Ar-Raudlatul } \\
\text { Hasanah Boarding } \\
\text { School }\end{array}$ & $\begin{array}{l}48 \text { years } \\
\text { old }\end{array}$ & Master & 29 years \\
\hline
\end{tabular}


QSPM respondents

\begin{tabular}{|c|c|c|c|c|c|}
\hline & $\begin{array}{c}\text { Name of } \\
\text { Respondent }\end{array}$ & Affiliation & Age & Education & $\begin{array}{c}\text { Working } \\
\text { Period }\end{array}$ \\
\hline 1 & Hendri Tanjung & $\begin{array}{l}\text { Member of } \\
\text { central BWI on } \\
\text { nazir } \\
\text { empowerment } \\
\text { division }\end{array}$ & $\begin{array}{c}49 \text { years } \\
\text { old }\end{array}$ & PhD & 3 years \\
\hline 2 & $\begin{array}{l}\text { Saparuddin } \\
\text { Siregar }\end{array}$ & $\begin{array}{l}\text { Head of waqf } \\
\text { Islamic State } \\
\text { University of } \\
\text { North Sumatra }\end{array}$ & $\begin{array}{l}57 \text { years } \\
\text { old }\end{array}$ & $\mathrm{PhD}$ & 19 years \\
\hline 3 & Taufiqurrahman & $\begin{array}{l}\text { Head of North } \\
\text { Sumatra Nazir } \\
\text { Forum }\end{array}$ & $\begin{array}{l}68 \text { years } \\
\text { old }\end{array}$ & Master & 5 years \\
\hline 4 & Ahmad Zuhri & $\begin{array}{l}\text { Head of BWI } \\
\text { Medan }\end{array}$ & $\begin{array}{l}49 \text { years } \\
\text { old }\end{array}$ & $\mathrm{PhD}$ & 3 years \\
\hline 5 & $\begin{array}{l}\text { Syariful Mahya } \\
\text { Bandar }\end{array}$ & $\begin{array}{l}\text { Head of BWI of } \\
\text { North Sumatra }\end{array}$ & $\begin{array}{l}67 \text { years } \\
\text { old }\end{array}$ & Master & $>2$ years \\
\hline
\end{tabular}

Additional Interviewees

1) Achmad Firdaus as a writer of a Book entitled "Maslahah Performa" on November 17, 2020.

2) Academician such as Tan Kamelo as supervisor of Tasbi waqf foundation on October 29, 2020; M. Yasir Nasution as waqf expert and ex-head of BWI North Sumatra on November 24, 2020. 